Research Paper

\title{
Kinetic characterization of glucose aerodehydrogenase from Aspergillus niger EMS-150-F after optimizing the dose of mutagen for enhanced production of enzyme
}

\author{
Huma Umbreen, Muhammad Anjum Zia, Samreen Rasul \\ Enzyme Biotechnology Laboratory, Department of Chemistry and Biochemistry, \\ University of Agriculture, Faisalabad, Pakistan.
}

Submitted: March 12, 2012; Approved: April 4, 2013.

\begin{abstract}
In the present study enhanced production of glucose aerodehydrogenase from Aspergillus niger has been achieved after optimizing the dose of chemical mutagen ethyl methane sulfonate (EMS) that has not been reported earlier. Different doses of mutagen were applied and a strain was developed basing upon the best production. The selected strain Aspergillus niger EMS-150-F was optimized for nutrient requirements in order to produce enzyme through fermentation and the results showed the best yield at $2 \%$ corn steep liquor (CSL), 36 hours fermentation time, $\mathrm{pH} 5,30^{\circ} \mathrm{C}$ temperature, $0.3 \%$ $\mathrm{KH}_{2} \mathrm{PO}_{4}, 0.3 \%$ urea and $0.06 \% \mathrm{CaCO}_{3}$. The enzyme was then purified and resulted in 57.88 fold purification with $52.12 \%$ recovery. On kinetic characterization, the enzyme showed optimum activity at $\mathrm{pH} 6$ and temperature $30^{\circ} \mathrm{C}$. The Michaelis-Menton constants $\left(\mathrm{K}_{\mathrm{m}}, \mathrm{V}_{\mathrm{max}}, \mathrm{K}_{\text {cat }}\right.$ and $\left.\mathrm{K}_{\mathrm{cat}} / \mathrm{K}_{\mathrm{m}}\right)$ were $20 \mathrm{mM}, 45.87 \mathrm{U} \mathrm{mL}^{-1}, 1118.81 \mathrm{~s}^{-1}$ and $55.94 \mathrm{~s}^{-1} \mathrm{mM}^{-1}$, respectively. The enzyme was found to be thermaly stable and the enthalpy and free energy showed an increase with increase in temperature and $\Delta \mathrm{S}^{*}$ was highly negative proving the enzyme from $A$. niger EMS-150-F resistant to temperature and showing a very little disorderliness.
\end{abstract}

Key words: glucose aerodehydogenase, mutagenesis, production, purification, thermal stability.

\section{Introduction}

Microbial glucose aerodehydrogenase is currently receiving much attention due to its wide applications in chemical, pharmaceutical, food, beverage, clinical chemistry, biotechnology and other industries. It is also called as glucose oxidase and catalyzes the oxidation of $\beta$-D-glucose to gluconic acid by utilizing the molecular oxygen with simultaneous production of hydrogen peroxide. Of several microbial enzymes known for causing the oxidation of glucose, the best known is glucose aerodehydrogenase (Banker et al., 2009). Glucose aerodehydrogenase is naturally produced enzyme by some insects as honey bee (Santos et $a l ., 2005)$ and grass hopper (Jacques, 2005) etc. It has been extracted from various micro-organisms as Penicillium notatum, Penicillium chrysosporium, Penicillium amagasakiense (Witt et al., 2000), Aspergillus niger and Botrytis cinerea (Liu et al., 1998) but majority of its commercial preparations are being obtained from A. niger (Hatzini- kolaou et al., 1996). It is successfully for industrial scale because it is metabolically versatile strain and is regarded as the mostly used and important species of fungus for production and extraction of catalytic proteins (Zia, 2007). It is stable on mutagenesis and does not cause problems on treatment with mutagens (Bosch et al., 1995).

The main problems that are often complained about the enzyme production and stability are low productivity and loss of activity at increased temperature and fluctuating $\mathrm{pH}$ at industrial processes. To overcome such obstructions, mutated strains rather than native one are preferred to ferment such enzymes having better industrial effectiveness. A. niger is a versatile fungus for mutagenesis for increased enzyme production (Crognal et al., 2006). Only a few reports are there that describe the mutagenesis and selection of $A$. niger for increased production of glucose aerodehydrogenase, but none has been reported yet about optimizing a chemical mutagen dose (EMS) with an increased and a stable activity of the enzyme. In the present

Send correspondence to M.A. Zia. Enzyme Biotechnology Lab., Department of Chemistry and Biochemistry, University of Agriculture, Faisalabad-38040, Pakistan. E-mail: scientistuaf@yahoo.com. 
study enhanced production, kinetic and thermodynamic stability has been reported after optimizing the dose of ethyl methane sulfonate (EMS) i.e. a potent mutagen for microbes.

\section{Materials and Methods}

All the chemicals and reagents used in this research work were of analytical grade and purchased from Oxoid, Sigma, Fluka and Riedel-de Haen etc. The organisms (parent Aspergillus niger EBL and mutant Aspergillus niger EMS-150-F) were procured from Enzyme Biotechnology Lab., Department of Chemistry and Biochemistry, University of Agriculture, Faisalabad. The parent strain was isolated from soil and was verified by Department of Pathology, University of Agriculture Faisalabad, Pakistan. Stock culture was maintained on Potato-Dextrose-Agar media (PDA) and refrigerated at $4{ }^{\circ} \mathrm{C}$ until its use.

The spores of Aspergillus niger EBL from PDA media were inoculated in a conical flask having $50 \mathrm{~mL}$ of Vogel's media ( $\mathrm{pH}$ 5.5), which was kept in a rotary shaker at $120 \mathrm{rpm}$ and $30{ }^{\circ} \mathrm{C}$ temperature for 24-36 hours (Zia et al., 2010). To get the enhanced production of glucose aerodehydrogenase the organism was subjected to ethyl methane sulfonate (EMS) exposure (Khattab and Bazaraa, 2005) at dose of 100, 150, 200 and $250 \mathrm{mM}$. Each specific dose of $1 \mathrm{~mL}$ was added in $9 \mathrm{~mL}$ of Vogel's inoculum in a flask. The fractions of $1 \mathrm{~mL}$ were collected at different time intervals of $30,60,90,120,150$ and $180 \mathrm{~min}$. The fractions collected were centrifuged twice for $15 \mathrm{~min}$. at 10,000 rpm so as to give out the mutagen from spores in the suspension (Khattab and Bazaraa, 2005; Zia, 2007). The EMS exposed culture was inoculated on PDA media containing $1 \%$ triton $\mathrm{X}-100$ as colony restrictor (Rakariyatham et al., 2006; Iftikhar et al., 2010). In order to get the dose with best glucose aerodehydrogenase production, enzyme diffusion zone test was employed on agar media containing o-dianisidine and horseradish peroxidase, which gives brown color (Khattab and Bazaraa, 2005).

The best selected strain, A. niger EMS-150-F was used in submerged fermentation for optimization of glucose aerodehydrogenase production media. These parameters include carbon sources at various levels [corn steep liquor (CSL), molasses, rice polishing and sludge), fermentation period (18, 36, 45, 70 and $96 \mathrm{hrs}$.), $\mathrm{pH}(4,4.5$, $5,5.5,6,6.5$ and 7$)$, temperature $\left(4,20,30,37\right.$ and $\left.45^{\circ} \mathrm{C}\right)$, urea $(0,0.1,0.3,0.5,0.7$ and $0.9 \%), \mathrm{KH}_{2} \mathrm{PO}_{4}(0,0.1,0.3$, $0.5,0.7$ and $0.9 \%), \mathrm{CaCO}_{3}(0,0.01,0.03,0.06,0.09$ and $0.12 \%)$ and $\mathrm{MgSO}_{4} .7 \mathrm{H}_{2} \mathrm{O}(0,0.01,0.02,0.03,0.04,0.5$ and $0.06 \%)$ ]. These trials were carried out in triplicate and after each step of optimization the enzyme was checked for activity (Worthington, 1988) based on the principle that the velocity of the reaction is determined by an increase in absorbance at $460 \mathrm{~nm}$ that is resulted by the oxidation of o-dianisidine through a peroxidase coupled system. One unit causes the oxidation of one $\mu$-mole of o-dianisidine in one minute at $30^{\circ} \mathrm{C}$ and $\mathrm{pH} 6.0$ under the specified conditions. Biuret method was used to estimate protein content of the samples (Rasul et al., 2011).

\section{Purification and characterization}

Crude extract of the enzyme was saturated at $60-80 \%$ ammonium sulfate then was subjected to DEAE-cellulose and Sephadex G-150 for purification that was analyzed by SDS-PAGE (Shin et al., 1993; Sukhacheva et al., 2004). Optimum $\mathrm{pH}$ was determined by assaying the mutant derived enzyme at 4-8.5 $\mathrm{pH}$ range and at different temperatures $\left(4,20,30,37\right.$ and $\left.45^{\circ} \mathrm{C}\right)$ to seek the optimal values (Sukhacheva et al., 2004). Activation energy was determined by assaying at different temperatures ranging from 20-80 ${ }^{\circ} \mathrm{C}$ and entering data in Arhennius plot (Lino and Teresa, 1998). The Mechalis-menton kinetic constant $\mathrm{K}_{\mathrm{m}}$ and $\mathrm{V}_{\mathrm{max}}, \mathrm{K}_{\mathrm{cat}}$ and $\mathrm{K}_{\mathrm{cat}} / \mathrm{K}_{\mathrm{m}}$ were determined by assaying the different concentrations of glucose $(12,15,18,21,24 \%)$ as described (Leiter et al., 2004).

For the determination of thermal denaturation of the enzyme the method described (Rajoka et al., 2006) was followed. Data obtained was plotted in first order plot and was analyzed. The thermodynamic parameters for thermostability were calculated by rearranging the Eyring's absolute rate equation derived from the transition state theory.

\section{Statistical analysis}

Data obtained was analyzed by statistical method described by Steel et al. (1997). MS Excel and slide write plus softwares were used to draw graphs.

\section{Results and Discussion}

Development of the superior strains through mutagenesis has become a recurrently used practice. Strain developers have searched for improved strains among random survivors of mutagenesis. Microbiologist and biochemists often try to apply some practices that may be through physical or chemical means so as to improve certain required characteristics in a strain and to decrease or eliminate the factors that are undesirable (Gadgil et al., 1995). Although chemical and physical mutagenesis induce mutations nonrandomly causing the mutations that are not site or gene specific and may have their effect more at some sites than has been expected but it is still cost effective procedure for strain development with desired characteristics (Rowlands, 1984). Ethyl methane sulfonate is a carcinogen which has been documented and reported to cause mutagenesis in microorganisms (Lino and Teresa, 1998; Rakariyatham et al., 2006).

Kill curve has been used to know the best time of mutagenesis for each dose. It helps to determine the best mutant with the capacity to produce more glucose aerodehydrogenase (Zia, 2007). To obtain an instant mutation a high 
dose of mutagen is required as the results of kill curve (Table 1) have shown an increase in killing with time and increase in dose. The best dose was found to be $200 \mathrm{mM}$ with killing \%age of 79.4 at 150 min EMS exposure. The dose with $250 \mathrm{mM}$ EMS resulted in killing \%age less than that of $200 \mathrm{mM}$ dose which can be attributed to the development of resistance against the chemical mutagen developed with time. Khataab and Bazaraa (2005) also used EMS as mutagen but have used only a single dose of $200 \mathrm{mM}$ that also showed in an increase in activity after mutagenesis and resulted in an augmented resistance with further exposure to the mutagen.

For the selection of mutant, after mutagenesis the dilutions were plated on agar media containing $1 \%$ triton $\mathrm{X}-100$ to restrict the colonies that was also used earlier (Elkeles et al., 1994; Khattab and Bazaraa, 2005). Plate screening method was used to check the potential of the colonies to grow and then enzyme diffusion zone test was employed to screen and to identify the mutant strain. The zone size of the EMS-150-F was found to be $16 \mathrm{~mm}$ as compared to the control which was $9 \mathrm{~mm}$ (Figure 1). The zone size analyzed for EMS treated strain was the maximum with $14 \mathrm{~mm}$ (Khattab and Bazaraa, 2005), which clearly indicates the dominance of enzyme obtained in the present study, as there is a strong relation between the activity and zone size in enzyme diffusion zone test.

\section{Production of enzyme}

As the mutant strain $A$. niger EMS-150-F may has a modified genotype so optimization of culture condition is necessary to reveal the actual potential. Therefore a series of consecutive experiments were performed in shaken flasks to determine the effect of medium composition on glucose aerodehydrogenase from this mutant strain (Petruccioli et al., 1997). The effect of using different carbon sources is very imperative for the fermentation process. There is always a quest for an economical but with better production substrate. During the fermentation process of microbes, the carbon source acts as the most important nutrient for building of the material required for the synthesis of the cells and is also a vital as energy provider. Out of four carbon sources used, CSL at $2 \%$ was found to be the best with optimum activity.

Fermentation time is an important factor for the synthesis of the enzyme from the microorganism, as there comes a time when running down of nutrients in the medium

Table 1 - Optimization of mutagen dose, formulated from kill curve.

\begin{tabular}{lcc}
\hline Dose & Killing \% age $(\% \pm$ SEM) & Optimum dose (min.) \\
\hline $100 \mathrm{mM}$ & $65 \pm 0.362$ & 120 \\
$150 \mathrm{mM}$ & $71.64 \pm 0.147$ & 150 \\
$200 \mathrm{mM}$ & $79.4 \pm 0.132$ & 150 \\
$250 \mathrm{mM}$ & $78.3 \pm 0.255$ & 150 \\
\hline
\end{tabular}

or amassing of some auto-toxic products in the medium may bound the enzyme production rate. The present study has resulted in highest activity at 36 hours of fermentation while Banker et al. (2009) have observed an optimum growth at 96 hours after which a drastic decline was observed, while in a study of glucose aerodehydrogenase production from mutant Penicillium funiculosum, the maximum yield of enzyme was observed at 52 hours of cultivation. Thus an improved enzyme production has been obtained without wasting too much time in the present study.
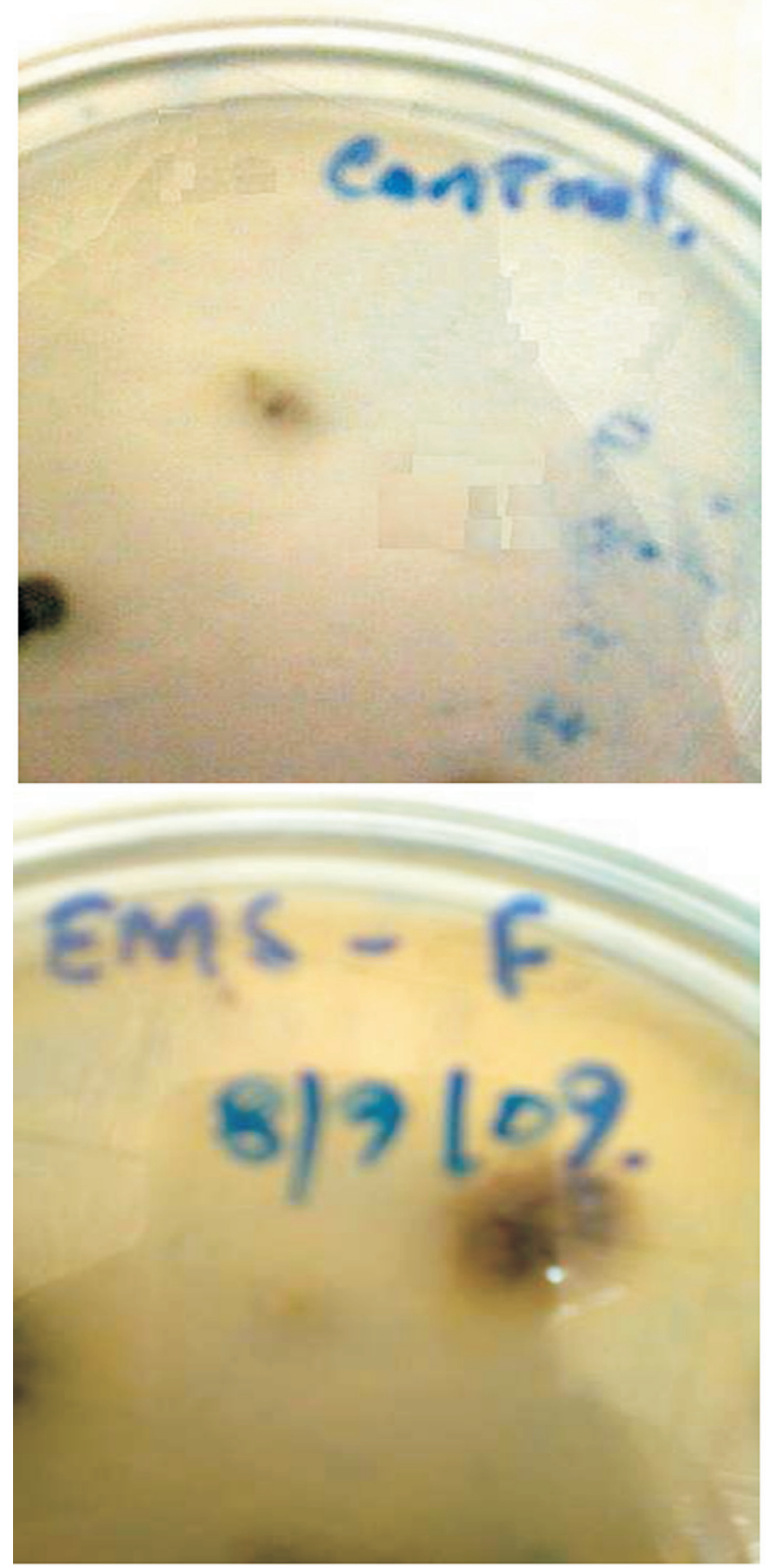

Figure 1 - Enzyme diffusion zone test for control and EMS-150-F. 
The optimum production was obtained at $\mathrm{pH} 5$ and $30{ }^{\circ} \mathrm{C}$ temperature, while Sabir et al. (2007) observed the optimum pH to be 6 and Hamid et al. (2003) found it to be 3. The difference can be attributed to the mutated strain having pre-requisite different from that of natural one. The concentration of urea as nitrogen source in growth medium is of extensive importance for the production of enzyme from fungi. The microorganisms require an adequate supply of nitrogen source for various metabolic activities. The optimum activity of enzyme was observed at $0.3 \%$ of urea, which is in accordance with that of (Rasul et al., 2011).

Different concentrations of $\mathrm{MgSO}_{4} .7 \mathrm{H}_{2} \mathrm{O}$ were tested out for their consequence on activity of glucose aerodehydrogenase from $A$. niger EMS-150-F that resulted in a downfall effect with increase in concentration of $\mathrm{MgSO}_{4}$. It has been demonstrated the same conclusion suggesting that addition of $\mathrm{Mg}^{+}$strongly inhibits production of glucose aerodehydrogenase (Petruccioli et al., 1997). $\mathrm{CaCO}_{3}$ besides acting as buffering agent provides support for growth and also substantially induces glucose aerodehydrogenase activity. Results depict an abrupt increase in activity of the enzyme from $A$. niger EMS- $150-\mathrm{F}$ at $0.06 \%$ of calcium carbonate. The increase in activity by adding calcium carbonate is due to the fact that it causes a transfer of metabolism from glycolytic pathway to direct oxidation of glucose by enzyme (Liu et al., 2001). Potassium and phosphate salts were supplemented to the medium to enhance the production of enzyme in growth culture. $\mathrm{KH}_{2} \mathrm{PO}_{4}$ as potassium and phosphorus source was found to bestow an optimum production at $0.3 \%$, showing cost-benefit ratio of the production in the present study. All of these results are statistically significant and have been shown in Figure 2.

\section{Purification of glucose aerodehydrogenase}

After ammonium sulfate precipitation and desalting, specific activity was increased to $45.07 \mathrm{U} \mathrm{mg}^{-1}$. The enzyme produced by the mutant strain $A$. niger EMS-150-F had attained 2.58 fold purification and $94.15 \%$ recovery as compared to the crude enzyme. Ion exchange chromatography exploits differences in signs and magnitude of net electric charge of protein at given $\mathrm{pH}$. DEAE-cellulose resulted in 73.12 fold purification and \%age recovery was obtained to be 74.59. After the purification of the enzyme through ion exchange chromatography it was further purified by gel filtration chromatography that isolates the proteins according to molecular size. It resulted in the highest specific ac-

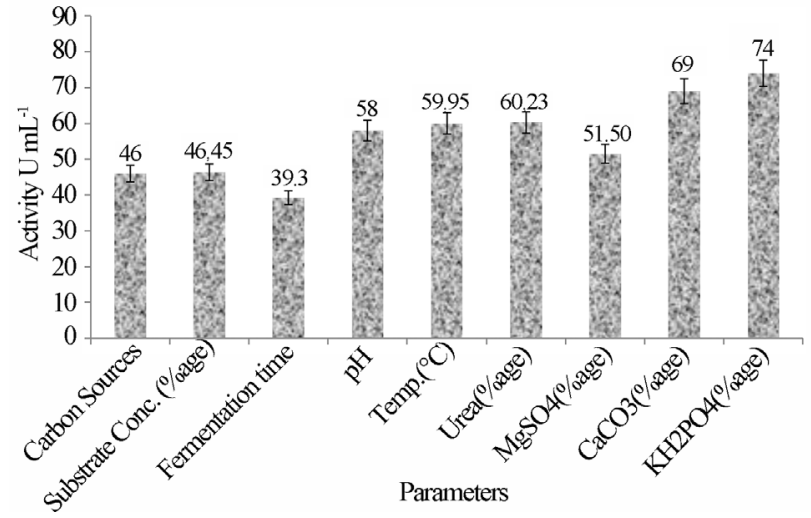

Figure 2 - Change in activity $\left(\mathrm{U} \mathrm{mL}^{-1} \pm \mathrm{SEM}\right)$ of the enzyme with gradual optimization of nutrients for A. niger EMS-150-F.

tivity of $1962.59 \mathrm{U} \mathrm{mg}^{-1}$ having 112.59 fold purification and $67.07 \%$ recovery (Table 2 ). The purity of the enzyme was analyzed by SDS-PAGE that indicated that enzyme is a dimer and both monomers have the molecular weight near $67 \mathrm{kDa}$ (Figure 3).

Such findings are in accordance with the results of various researchers (Sukhacheva et al., 2004; Bhatti and Saleem, 2009; Rasul et al., 2011) who found an increase of specific activity of glucose aerodehydrogenase after each purification step. Bhatti and Saleem (2009) have obtained a specific activity of $280 \mathrm{U} \mathrm{mg}^{-1}$, with 16.47 fold purification and $15 \%$ yield after complete purification of the enzyme from Penicillium notatum that is far less than that is observed in the present study.

\section{Characterization of enzyme}

In view of the fact that $\mathrm{pH}$ shows a prevailing task in the activity, as glucose aerodehydrogenase from Aspergillus niger was found to loss its activity by $12 \%$ when kept at $\mathrm{pH}$ higher than 8 in a stability test performed earlier (Ferreira et al., 2005). So a pH range from 4-8.5 was checked for optimum enzymatic activity. The results obtained have depicted that enzyme showed a good activity between the $\mathrm{pH}$ range of 4-8.5, with activity of $39.7 \mathrm{U} \mathrm{mL}^{-1}$ at $\mathrm{pH} 6$ (Figure 4). These results are exactly same where optimum $\mathrm{pH}$ was obtained at 6 for $A$. niger glucose aerodehydrogenase (Ko et al., 2002). In contrast the enzyme produced from $A$. niger EMS-150-F in the present study is stable as compared to obtained from Penicillium pinophilum that was found unstable in $\mathrm{pH}$ range of 2-4 and

Table 2 - Purification summary of glucose aerodehydrogenase from A. niger EMS-150-F.

\begin{tabular}{|c|c|c|c|c|c|}
\hline Purification Step & Activity $\left(\mathrm{U} \mathrm{mL}^{-1}\right)$ & Protein $\left(\mathrm{mg} \mathrm{mL}^{-1}\right)$ & Specific activity $\left(\mathrm{U} \mathrm{mg}^{-1}\right)$ & Fold purification & $\%$ age recovery \\
\hline Crude & 79 & 4.53 & 17.43 & 1 & 100 \\
\hline Ammonium sulfate desalted & 74.38 & 1.65 & 45.07 & 2.58 & 94.15 \\
\hline DEAE-cellulose & 58.93 & 0.046 & 1274.63 & 73.12 & 74.59 \\
\hline Sephadex G-150 & 52.99 & 0.041 & 1962.59 & 112.59 & 67.07 \\
\hline
\end{tabular}




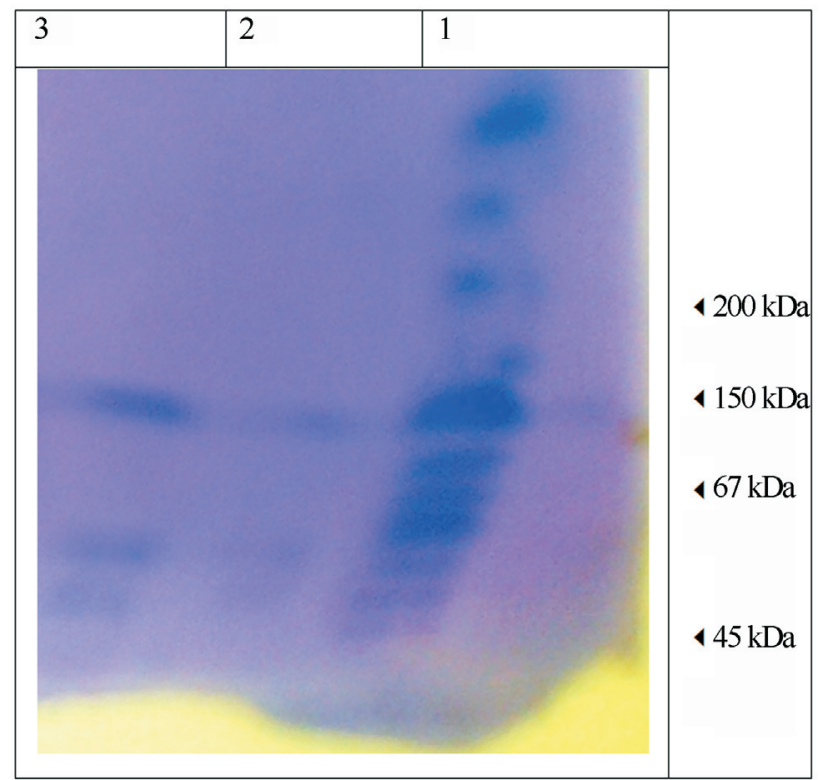

Figure 3 - SDS-PAGE of glucose aerodehydrogenase (Lane 1 is marker and purified enzyme loaded in duplicate Lanes $2 \& 3$ ).

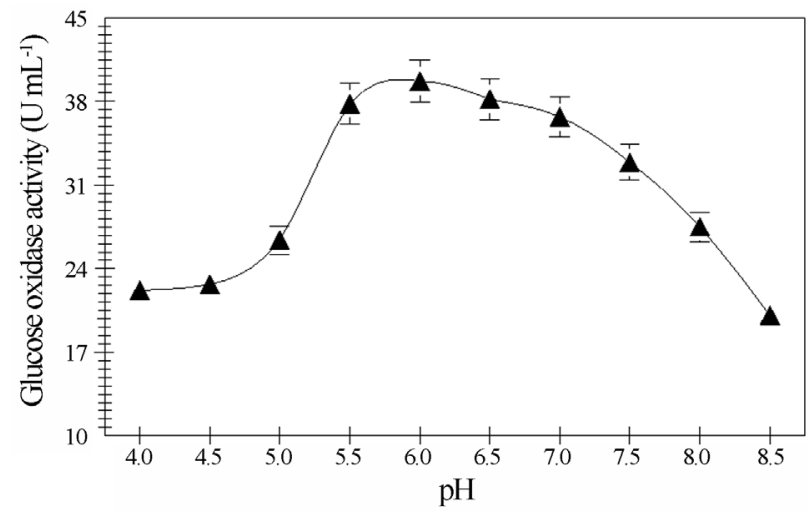

Figure 4 - Effect of $\mathrm{pH}( \pm \mathrm{SEM})$ on glucose aerodehydrogenase from $A$. niger EMS-150-F.

above 7 (Rando et al., 1997). In another study on glucose aerodehydrogenase, the results had shown that the rate of reaction augmented with raise in $\mathrm{pH}$ of the medium, however as the $\mathrm{pH}$ became immense, the rates started to decline and showed a greatest at pH 6.5 (Lino and Teresa, 1998).

Change in temperature causes a change in the activity of the enzyme, so the enzyme from A. niger EMS-150-F was observed for its stability on the basis of temperature. It was observed that enzyme had an optimum temperature of $30{ }^{\circ} \mathrm{C}$ (Figure 5). The energy of activation derived from the Arhennius plot (Figure 6) was $7.45 \mathrm{~kJ} \mathrm{~mol}^{-1}$. The enzyme is active over a wide range depicting it a stable for industrial scale production and to accept the higher temperatures, if employed. Similarly glucose aerodehydrogenase from $P$. amagassakiense showed a wide range of the temperature for enzyme performance (Witt et al., 1998). Glucose aerodehydrogenase catalyzed reaction was deliberated at di-

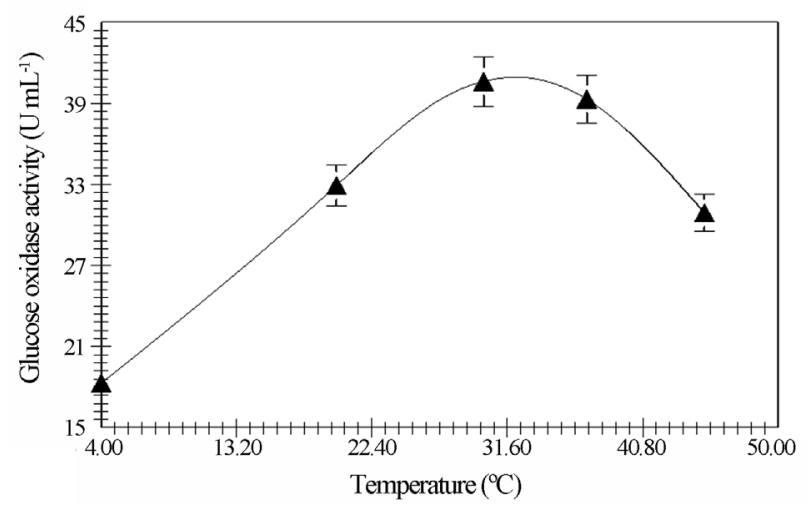

Figure 5 - Effect of temperature $\left({ }^{\circ} \mathrm{C} \pm \mathrm{SEM}\right)$ on glucose aerodehydrogenase from A. niger EMS-150-F.

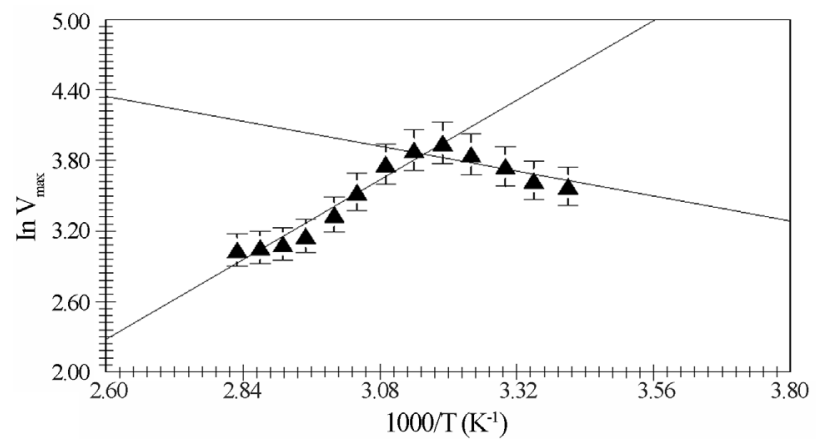

Figure 6 - Arhennius plot for energy of activation of glucose aerodehydrogenase.

verse temperatures from $25-60{ }^{\circ} \mathrm{C}$ that resulted in increased reaction velocities with increase in temperature (Lino and Teresa, 1998). It further obtained activation energy of $28.9 \mathrm{~kJ} \mathrm{~mol}^{-1}$, showing higher activation energy as compared to the present study. So, it can be concluded that glucose aerodehydrogenase from $A$. niger EMS-150-F is superior as compared to earlier studied reports as it necessitates a lesser amount of energy to start up the reaction.

Glucose aerodehydrogenase from fungal sources (Aspergillus niger) has a low $\mathrm{K}_{\mathrm{m}}$ ranging from $0.11-33 \mathrm{mM}$. The values observed in the present study have clear indication of the above described results and are in accordance with it (Figure 7). The values obtained are $20 \mathrm{mM}, 45.87 \mathrm{U} \mathrm{mL}^{-1}, 1118.81 \mathrm{~s}^{-1}$ and $55.94 \mathrm{~s}^{-1} \mathrm{mM}^{-1}$ for $\mathrm{K}_{\mathrm{m}}, \mathrm{V}_{\text {max }}, \mathrm{K}_{\text {cat }}$ and specificity constant, respectively, evaluating the enzyme perfect for the production and exploit as catalyst at industrial level. It is further reported that enzyme from mutant Aspergillus niger have $\mathrm{K}_{\mathrm{m}}$ and $\mathrm{V}_{\max }$ as $28 \mathrm{mM}$, $60 \mathrm{U} \mathrm{mL}^{-1}$, respectively (Zia, 2007). A low $\mathrm{K}_{\mathrm{m}}$ value in the present study as compared to the earlier ones depicts its higher affinity and specificity for glucose as substrate.

Each enzyme is thermodynamically stable within a particular temperature and $\mathrm{pH}$ range and can transform its activity from higher to lower at some transition temperature. The development of methodologies that can increase 


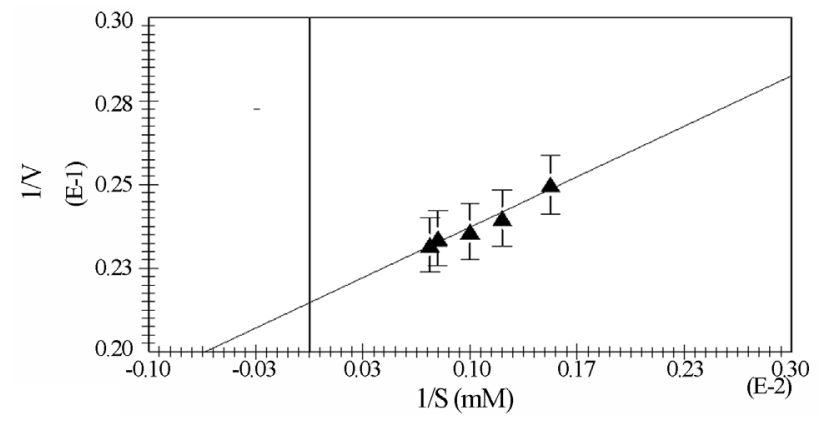

Figure 7 - Line-weaver Burk plot for glucose aerodehydrogenase from $A$. niger EMS-150-F.

enzyme stability is an important goal in enzyme technology. The enzyme from EMS-150-F was thermally stable as at $40{ }^{\circ} \mathrm{C}$ with half life of 93.64 min which gradually decreased with increase in temperature to $80{ }^{\circ} \mathrm{C}$ (Figure 8). Protein molecules show only a certain degree of stability especially at elevated temperatures. Thermal denaturizing of multimeric enzymes is paralleled by the distraction of non-covalent bonds leading to subunit dissociation with an affiliated augmentation in the enthalpy of activation (Rodriguez-Nogales, 2004; Srivastava et al., 2005). The unfolding of enzyme configuration causes a raise in mess, uncertainty or entropy of activation (Vieille and Zeikus, 1996). The results obtained in the present study (Table 3; Figure 8) have portrayed that enthalpy has increased in the range of $0.541-0.611 \mathrm{~kJ} \mathrm{~mol}^{-1}$ with increase in temperature from $40-80^{\circ} \mathrm{C}(313-353 \mathrm{~K})$. The Gibb's free energy calculated had also a constant trend to increase with rise in temperature, with its maximum value at $80{ }^{\circ} \mathrm{C}$ i.e. $96.36 \mathrm{~kJ}$ $\mathrm{mol}^{-1}$ presenting that the enzyme has exhibited the resistance against thermal unfolding at higher temperatures. The entropy of the system was found to be $-271.24 \mathrm{~J} \mathrm{~mol}^{-1} \mathrm{~K}^{-1}$ at $80^{\circ} \mathrm{C}$. The decidedly negative value of entropy of inactivation $\left(\Delta \mathrm{S}^{*}\right)$ observed for glucose aerodehydrogenase in the present case has suggested that there was negligible disorderliness, indicating that enzyme is thermodynamically much stable. In contrast to the results in the present study Bhatti and Saleem (2009) and Zia (2007) have observed

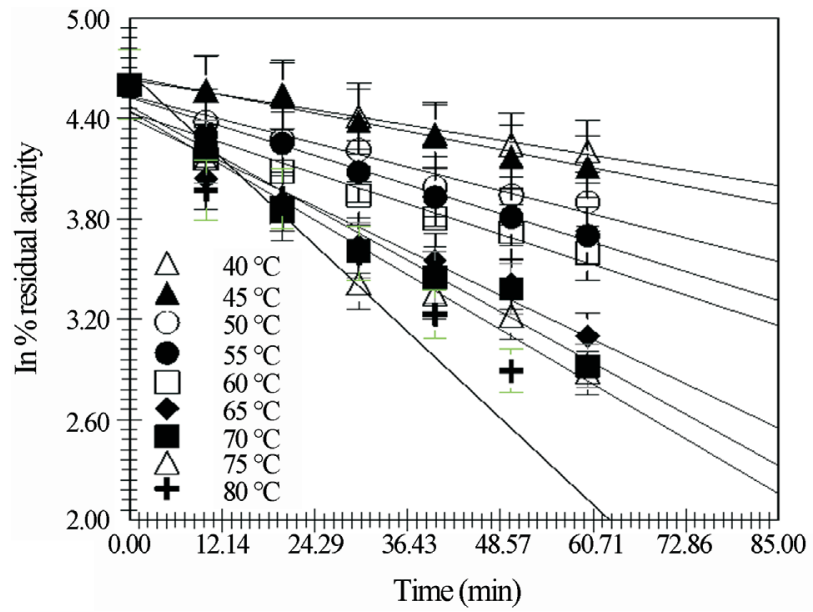

Figure 8 - Irreversible thermal denaturation of glucose aerodehydrogenase from $A$. niger EMS-150-F.

higher entropy with -96.12 and $-11.92 \mathrm{~J} \mathrm{~mol}^{-1} \mathrm{~K}^{-1}$ respectively showing more randomness with increase in temperature as a result of opening of the enzyme structure. Comparison with the other studies clearly indicates the present enzyme as more ordered in transition state and more resistant and stable at higher temperatures.

\section{Conclusion}

On the basis of the above described results it can be concluded appropriately that mutagenesis with $200 \mathrm{mM}$ EMS has resulted in such glucose aerodehydrogenase from Aspergillus niger EMS-150-F that has a higher activity. This modified novel enzyme is kinetically and thermodynamically much stable enzyme which can resist at higher temperature $\left(40-80^{\circ} \mathrm{C}\right)$ and has a wide $\mathrm{pH}$ range (4-8) required for production at industrial scale. It has lower activation energy to avoid the losses of energy just to start up the working of the enzyme. The enzyme is unique with its higher half life and resistance against thermal unfolding at higher temperatures that are usually required for its production processes. Moreover, it has a negligible randomness

Table 3 - Kinetic and thermodynamic parameters for irreversible thermal inactivation of glucose aerodehydrogenase from A. niger EMS-150-F.

\begin{tabular}{lccccc}
\hline Temperature $(\mathrm{K})$ & $\mathrm{K}_{\mathrm{d}}\left(\mathrm{min}^{-1}\right)$ & $\mathrm{t}_{1 / 2}(\mathrm{~min})$ & $\Delta \mathrm{H}^{*}\left(\mathrm{~kJ} \mathrm{~mol}^{-1}\right)$ & $\Delta \mathrm{G}^{*}\left(\mathrm{~kJ} \mathrm{~mol}^{-1}\right)$ & $\Delta \mathrm{S}^{*}\left(\mathrm{~J} \mathrm{~mol}^{-1} \mathrm{~K}^{-1}\right)$ \\
\hline 313 & 0.007 & 93.64 & 0.541 & 89.65 & -284.69 \\
318 & 0.008 & 77.52 & 0.549 & 90.64 & -283.31 \\
323 & 0.116 & 59.54 & 0.558 & 91.42 & -281.31 \\
328 & 0.014 & 48.53 & 0.567 & 92.32 & -279.93 \\
333 & 0.015 & 46.32 & 0.576 & 93.61 & -279.38 \\
338 & 0.022 & 31.76 & 0.584 & 94.01 & -276.41 \\
343 & 0.025 & 27.44 & 0.593 & 95 & -275.23 \\
348 & 0.026 & 25.77 & 0.602 & 96.27 & -274.91 \\
353 & 0.042 & 16.29 & 0.611 & 96.36 & -271.24 \\
\hline
\end{tabular}


depicting its ability to survive at the higher temperatures that are often complained by the enzyme users as biocatalyst and its production and availability at assorted levels.

\section{Acknowledgments}

This research work was financially supported by Higher Education Commission, Pakistan, through grant No. 1119 to Dr. M. Anjum Zia and done for M.Phil. theses of Huma Umbreen and Samreen Rasul, carried out at Enzyme Biotechnology Lab., Univ. of Agriculture, Faisalabad.

\section{References}

Banker SB, Bule MV, Singhal RS, Ananthanarayan L (2009) Glucose oxidase: an overview. Biotechnol Adv 27:489-501.

Bhatti HN, Saleem N (2009) Characterization of glucose oxidase from Penicillium notatum. Food Technol Biotehnol 47:331-335.

Bosch A, Marrona RA, Yantorno OM (1995) A simple descriptive model of filamentous fungi spore germination. Process Biochem 30:599-606.

Crognal S, D'Annibal A, Federici F, Fenice M, Quaratino D, Petruccioli M (2006) Olive oil mill wastewater valorisation by fungi. J Chem Technol Biotechnol 81:1547-1555.

Elkeles A, Rosenberg E, Ron EZ (1994) Azide resistant mutant in Acinitobactor calacoaceticus A2 are defective in protein secretion. FEMS Microbiol Lett116:211-224.

Ferreira LFP, Taqueda ME, Converti A, Vitolo M, Pessoa Jr A (2005) Purification of glucose oxidase from Aspergillus niger by liquid-liquid cationic reversed micelles extraction. Biotechnol Prog 21:868-874.

Gadgil NJ, Daginawala HF, Chkrabarti T, Khanna P (1995) Enhanced cellulose production by a mutant of Trichoderma reesei. Enz Microbiol Technol 17:942-946.

Hamid HM, Rehman K, Zia MA, Asgher M (2003) Optimization of various parameters for the production of glucose oxidase from rice polishing using Aspergillus niger. Biotechnol 2:1-7.

Hatzinikolaou DG, Hansen OC, Macris BJ, Tingey A, Kekos D, Goodenough P, Stougaard P (1996) A new glucose oxidase from Aspergillus niger: characterization and regulation studies of enzyme and gene. Appl Microbiol Biotech 46:371381.

Iftikhar T, Niaz M, Hussain Y, Abbas SQ, Ashraf I, Zia MA (2010) Improvement of selected strains through gamma irradiation for enhanced lipolytic potential. Pak J Bot 42:22572267.

Jacques MM, Bede JC (2005) Influence of diet on larval beet armyworm Spodoptera exigua glucose oxidase activity. J Ins Sci 5:1-9.

Khattab AA, Bazaraa WA (2005) Screening, mutagenesis and protoplast fusion of Aspergillus niger for the enhancement of extracellular glucose oxidase production. J Ind Microbiol Biotechnol 32:289-294.

Ko JH, Hahm MS, Kang HA, Nam SW, Chung BH (2002) Secretory expression and purification of Aspergillus niger glucose oxidase in Saccharomyces cerevisiae mutant deficient in PMR1 gene. Protein Exp Purif 25:488-493.
Leiter E, Marx F, Pusztahelyi T, Haas H, Pocsi I (2004) Penicillium chrysogenum glucose oxidase: A study on its anti-fungal effects. J Appl Microbiol 97:1201-1209.

Lino MR, Teresa PN (1998) Isolation of hyperxylanolytic Cellulomonas flavigena mutant growing in continuous culture. Biotechnol Lett 20:443-446.

Liu JZ, Huang YY, Liu J, Weng LP, Ji LN (2001) Effect of metal ions on simultaneous production of glucose oxidase and catalase by Aspergillus niger. Lett Appl Microbiol 32:16-19.

Liu S, Oelejekaus S, Gerhardt B, Tudzynki B (1998) Purification and characterization of glucose oxidase of Botrytis cinerea. J Physiol Mol Plant Pathol 53:123-132.

Petruccioli M, Piccioni P, Fenice M, Federicci F (1997) Glucose oxidase, catalase and gluconic acid production by immobilized mycelium of Penicillium variabile. Lett Biotechnol 16:939-942.

Rajoka MI, Rehman K, Tabish T, Zia MA (2006) Purification and characterization of caprine kidney uricase possessing novel kinetic and thermodynamic properties. World J Microbiol Biotechnol 22:289-291.

Rakariyatham N, Butr-Indr B, Niamsup H, Shank L (2006) Improvement of myrosinase activity of Aspergillus sp. NR4617 by chemical mutagenesis. Electro J Biotechnol 9:815-821.

Rando D, Kohring GW, Giffhorn F (1997) Production, purification and characterization of glucose oxidase from a newly isolated strain of Penicillium pinophilum. Appl Microbiol Biotechnol 48:34-40.

Rasul S, Zia MA, Sheikh MA, Iftikhar T (2011) Enhanced production and characterization of a novel $\beta$-D-glucose-oxygen-1-oxidoreductase by using $A$. niger UV-180-C mutant strain. Afr J Biotechnol 10:14522-14533.

Rodriguez-Nogales JM (2004) Kinetic behavior and stability of glucose oxidase entrapped in liposomes. J Chem Technol Biotechnol 79:72-78.

Rowlands RT (1984) Industrial strain development: mutagenesis and random screening procedure. Enz Microbiol Technol 6:3-10.

Sabir S, Bhatti HN, Zia MA, Shaikh MA (2007) Enhanced production of GOD using $P$. notatum and rice polishing. Food Technol Biotechnol 45:443-446.

Santos KS, Delazari SL, Mendes MA, Souza BM, Malaspina O, Palma MS (2005) Profiling the proteome complement of the secretion from hypopharyngeal gland of Africanized nurse honey bees (Apis malifera L.). Insect Biochem. Molec 35:85-91.

Shin KS, Youn HD, Han YH, Han SO, Hah YC (1993) Purification and characterization of D-glucose oxidase from white rot fungus Pleurotus ostreatus. Eur J Biochem 215:747-752.

Srivastava R, Brown JQ, Zhu H, Mc-Shane MJ (2005) Stabilization of glucose oxidase in alginate microspheres with photoreactive diazoresin nanofilm coatings. Biotechnol Bioeng 91:124-131.

Steel, RGD, Torrie JH, Dickey DA (1997) Principles and Procedures of Statistics - a Biometrical Approach. $3^{\text {rd }}$ Ed. McGraw-Hill, New York.

Sukhacheva MV, Devyova ME, Netrusov AI (2004) Production of Penicillium funiculosum 433 glucose oxidase and its properties. Appl Biochem Microbiol 40:25-29. 
Vieille C, Zeikus JG (1996) Thermozymes: Identifying molecular determinants of protein structural and functional stability. Trends Biotechnol 14:183-190.

Witt S, Wohlfahrt G, Schomberg D, Hecht HJ, Kalisz HM (2000) Conserved arginine-516 of Penicillium amagasakiense glucose oxidase is essential for the efficient binding of $\beta$ - D glucose. Biochem J 347:553-559.

Witt S, Singh M, Kalisz HM (1998) Structural and kinetic properties of non- glycosylated recombinant Penicillium amagasakiense glucose oxidase expressed in Escherichia coli. Appl Environ Microbiol 64:1405-1411.
Worthington CC (1988) Worthington Enzyme Manual: Glucose oxidase assay. Worthington Biochem Coop, Lakewood, USA.

Zia MA, Rahman K, Sheikh MA, Khan IA (2010) Chemically treated strain improvement of Aspergillus niger for enhanced production of glucose oxidase. Int $\mathrm{J}$ Agri Biol 12:964-966.

Zia MA (2007) Mutagenesis of Aspergillus niger for hyperproduction of glucose oxidase to prepare glucose diagnostic kit. Faisalabad, Pakistan. (Ph.D. thesis, Dept. of Chem. and Biochem., Uni. of Agri. Faisalabad).

All the content of the journal, except where otherwise noted, is licensed under a Creative Commons License CC BY-NC. 